\title{
Indonesian And Australian Tax Policy Implementation In Food And
}

\section{Agriculture Industry}

\author{
Hanggoro Pamungkas ${ }^{a}$, Maya Safira Dewi ${ }^{b}$, Yunita Anwar ${ }^{c}$, Martin Surya Mulyadi ${ }^{d}$ \\ a,b,c,d Bina Nusantara University, KH Syahdan 9, Jakarta 11480, Indonesia
}

\begin{abstract}
Tax policy is one of the most important policy in consideration of investment development in certain industry. Research by Newlon (1987), Swenson (1994) and Hines (1996) concluded that tax rate is one of the most important thing considered by investors in a foreign direct investment. One of tax policy could be used to attract foreign direct investment is income tax incentives. The attractiveness of income tax incentives to a foreign direct investment is as much as the attractiveness to a domestic investment (Anwar and Mulyadi, 2012).

In this paper, we have conducted a study of income tax incentives in food and agriculture industry; where we conduct a thorough study of income tax incentives and corporate performance in Indonesian and Australian food and agriculture industry. Our research show that there is a significant influence of income tax incentives to corporate performance. Based on our study, we conclude that the significant influence of income tax incentives to Indonesian corporate performance somewhat in a higher degree than the Australian peers. We have also concluded that Indonesian government provide a relatively more interesting income tax incentives compare to Australian government. However, an average method of net income - a method applied in Australia- could be considered by Indonesian government to avoid a market price fluctuation in this industry.
\end{abstract}

Keywords: tax policy; income tax incentives; food and agriculture industry; tax rate; foreign direct investment; domestic investment.

\section{C) 2014Published by SSBFNET}

\section{Introduction}

To support the development on certain industry, government usually issue a new policy. There are several kind of government policy which could be used and issued, ie: investment policy and tax policy. Tax policy is one of the most important thing to be considered in certain industry development. In considering a foreign direct investment, investors consider tax rate as one of the most important component (Newlon, 1987; Swenson, 1994; Hines, 1996). Location is also important determinant of a foreign direct investment (Ondrich and Wasylenko, 1993).

${ }^{\mathrm{a} C}$ orresponding author.Martin Surya Mulyadi. 
Income tax incentives are one kind of tax policy that could be used in effort to increase investment. Income tax incentives are a policy to change tax structure with several methods (Tung and Cho, 2001; Mulyadi, Anwar and Siagian, 2012). One example of income tax incentives which oftenly used is a reduction in tax rate as documented by Mintz and Smart (2004) in their research in Canada.

Another thing has to be accounted for is high cost of tax obligation, especially for a big business (Slemrod and Blumenthal, 1996). Therefore, there is no doubt that tax policy (in this case, income tax incentives) need to be seriously considered to attract foreign direct investment. Furthermore, this income tax incentives is also like a doubleedge sword: it is not only attracting foreign direct investment but also attracting domestic investment as well (Anwar and Mulyadi, 2012).

Food and agriculture industry is one of major industry both in Indonesia and Australia. Recent issues of food and agriculture industry was a deal by WTO Ministerial in Bali this December, which specifically dealing with food-stock holding and the price benchmark. Of course, this WTO deal also show the importance of government support for food and agriculture industry development.

Considering the importance of food and agriculture industry in Indonesia and Australia, and the importance of income tax incentives as tax policy to be implemented in support of a certain industry development, this paper will discuss tax policy implementation in Indonesian and Australian food and agriculture industry.

Second part of this paper will discuss the literature review regarding tax policy, income tax incentives in both countries and previous research. Research methodology will be described completely in third section and followed by discussion and analysis and conclusion. 


\section{Literature Review}

\subsection{Tax policy: income tax incentives}

Tax policy have a big impact, although sometimes it only has a little impact or no impact at all (Deskins, 2005). Based on Wasylenko (1997), he took a general conclusions that tax policy is a significant determinant of economic activities. This is due to tax system in a country consist of many kind of tax that influence overall economic activity, either corporate or personal economic activity (Anastassiou, 2011).

Several countries apply an income tax incentives to support investment in certain industry (Van Parys and James, 2010). Income tax incentives will attract investment as corporation which has received income tax incentives have a competitive advantage to their competitor (Fernandez de Soto Blass, 2011). According to Hutagaol, Darussalam and Septriadi (2006) there are three kind of income tax incentives:

Income tax incentives based on agreement with other country (government to government agreement) ie: tax treaty.

Agreement with contractor.

Income tax incentives based on government law and regulation.

Furthermore, Holland and Vann (1998) divide income tax incentives to five categories: tax holiday, investment allowances and tax credit, timing difference, tax rate reduction and free economic zones. Some technical issues are very important in tax holiday, especially related to impact of tax holiday to investment return. The most important thing in tax holiday is the start date of this income tax incentives. Tax holiday and tax rate reduction are among the most popular income tax incentives. There is difference between these two income tax incentives though. In tax holiday, corporate do not pay taxes in a certain period of time. While in tax rate reduction, corporate still need to pay taxes with lower tax rate compare to the other corporation.

\subsection{Income tax incentives in Indonesia}

In Indonesia, income tax incentives are given with various background, nature and objectives. In general, background, nature and objectives of the income tax incentives are an increased macroeconomic condition, which cover:

Boost domestic economic with income tax incentives.

Development of certain region.

Encourage a labour intensive industry.

Attract long term investment in Indonesia.

Increase income of lower-layer resident.

Increase income equality. 
Increase country's income.

Improvement of food and health issues.

Improvement of welfare.

Law basis of income tax incentives in Indonesia has been revised and improved several times. It was started in 2000 with Government Regulation 20/2000, and the latest law basis of income tax incentives that is still in effect is Government Regulation 52/2011 (applied since December 22, 2011). In this latest regulation, Indonesian government also include food and agriculture industry as income tax incentives recipient.

Income tax incentives provided by Indonesian government are regulated in Chapter 2 of Government Regulation $52 / 2011$. These income tax incentives will be given in case taxpayer realize at least $80 \%$ of their investment plan:

Reduction of net income. The amount of reduction is $30 \%$ of investment, which could be expensed equally throughout 6 years (5\% each year).

Accelerated depreciation and amortization. The useful life of Group I, II, III and IV is 2, 4, 8 and 10 years consecutively. While permanent building has 10 years useful life and 5 years of non-permanent building.

Special rate of income tax on dividend payable to foreign taxpayer. The tax rate is $10 \%$ or lower rate available based on applied tax treaties.

Extended loss carry forward, more than 5 years (normal period) and maximum 10 years.

To receive the above income tax incentives, besides the regulation of $80 \%$ investment realization there are more specific criteria outlined in the appendix of government regulation. The criteria cover product range, location and other special criteria. For example in agriculture industry, a corporation in mango cultivation business could receive income tax incentives if their location is in East Java and have land more than 500 hectare.

Another example from food industry, a corporation in milk processing business with product range of: milk powder, condensed milk and liquid milk could receive income tax incentives as long as their location is in: West Sumatera, Bengkulu, West Java, Central Java, Yogyakarta, East Java, Bali, West Nusa Tenggara and South Sulawesi with the following special criteria: minimum investment of 100 billion rupiah, minimum of 100 employees and minimum annual production of 50 tons.

\subsection{Income tax incentives in Australia}

In Australia, food and agriculture industry could receive income tax incentives if they are classified as primary producer. In Australian regulation, a business could be considered as a primary producer if it is a business (not merely a hobby) and also have to produce main production in the following category: land cultivation, maintenance of animals or poultry for the purpose of selling them or their bodily produce including natural increase, fishing operations, forest operations and horticulture. 
Primary producer could the following income tax incentives starting July 1, 2009. The following income tax incentives are not available in the other industry:

1. Immediate deductions for landcare operations.

2. Three year write off for water facilities.

3. Ten year write off for electricity connections and telephone lines.

4. Accelerated deductions for horticultural plants.

5. Deferral of profit on the forced disposal or death of livestock.

6. Deferral of profit on insurance recoveries.

7. Deferral of profit on double wool clips.

8. Income averaging.

Beside the above income tax incentives, there is also research and development tax incentives for Australian corporation. For tax year end or before June 30, 2011 this tax incentives in form of reduction and restitution with some terms and conditions. While for tax year start or after July 1, 2011, there are two tiers of research and development tax credit system. The two research and development tax credit system are:

1. Tax credit (could be restituted) amounted $45 \%$ of eligible research and development expenses.

2. Tax credit (could not be restituted) amounted $40 \%$ of research and development expenses.

\subsection{Previous research}

As has been discussed previously, income tax incentives are government policy to support investment in certain industry by altering the current tax structure. Previous research in tax structure in general have different analysis and different framework (Lambert, 1985; Atkinson, 1995; Creedy, 1995). The impact of income tax incentives to foreign direct investment has also been research subject of previous researcher. Root and Ahmed (1978) concluded that tax have impact on foreign direct investment and also investment decision in a multinational corporation.

Most of other researchers also conclude similarly based on their research, that tax policy is significant in investment/economic flow determination (Hartman, 1984; Young, 1988; Grubert and Mutti, 1991). Tung and Cho (2001) also concluded from their research in China, region with lower tax rate are more attractive to foreign direct investment compared to region with higher tax rate. Anwar and Mulyadi (2012) also concluded that income tax incentives given specifically in transportation industry have a significant impact to corporate performance.

Previous research in terms of comparison of Indonesian income tax incentives and other countries have been conducted in renewable energy industry (Anwar and Mulyadi, 2011), geothermal industry (Anwar and Mulyadi, 2011), transportation industry (Anwar and Mulyadi, 2012) and creative industry (Mulyadi, Anwar and Siagian, 2012). From their research, it could be concluded that some of income tax incentives provided by other country are comparatively more appealing compared to income tax incentives provided by Indonesia. However, it is worth to note though, that tax policy (income tax incentives) is only one variable out of many that is considered in an investment decision. 
Based on the previous research and literature review, we have developed the hypothesis to be tested in this research: the implementation of income tax incentives have a positive impact to corporate performance in Indonesian and Australian food and agriculture industry while the period of pre-implementation of income tax incentives have a negative impact to corporate performance in Indonesian and Australian food and agriculture industry.

\section{Research Methodology}

We are applying two research methodology in this paper. First, we apply a qualitative method by comparing income tax incentives in food and agriculture industry in Indonesia and Australia.

And second, to measure the impact of income tax incentives application to corporate performance, we used the following EGARCH econometric model.

$R_{t}=\sum_{i=1}^{n} d_{i} \delta_{i t}+\sum_{i=1}^{k} e_{i} R_{t-i}+\varepsilon_{t}$

where

$$
\begin{aligned}
\ln \left(\begin{array}{l}
2 \\
t
\end{array}\right)=\omega+\sum_{j=1}^{p} \beta \ln \left(\sigma_{t-1}^{2}\right)+\sum_{i=1}^{q} \gamma \frac{\mu t_{t-1}^{2}}{\sqrt{\sigma_{t-1}^{2}}}+\sum_{i=1}^{r} \alpha\left[\frac{\left|\mu_{t-1}\right|}{\sqrt{\sigma_{t-1}^{2}}}-\sqrt{\frac{2}{\pi}}\right] & =\text { dummy variable of income tax incentives period implementation } \\
\sum_{i=1}^{n} d_{i} \delta_{i t} & =\text { lag return } \\
\sum_{i=1}^{k} e_{i} R_{t-i} & =\text { error } \\
\mathcal{E}_{t} & =\text { impact of previous variance } \\
\sum_{j=1}^{p} \beta \ln \left(\sigma_{t-1}^{2}\right) & =\text { impact of previos error } \\
\sum_{i=1}^{r} \alpha\left[\frac{\left|\mu_{t-1}\right|}{\left.\sqrt{\sigma_{t-1}^{2}}-\sqrt{\frac{2}{\pi}}\right]}\right. & =\text { impact of asymmetries } \\
\sum_{i=1}^{q} \gamma \frac{\mu_{t-1}}{\sqrt{\sigma_{t-1}^{2}}} &
\end{aligned}
$$




\section{Discussion and analysis}

\subsection{Analysis of statistic test result}

We have chosen each 10 corporations both listed in Indonesia and Australia stock exchange. The statistic test result is available in Table 1.

Table 1. Statistic test result of corporate performance in Indonesia and Australia food and agriculture industry

\begin{tabular}{|c|c|c|c|c|c|}
\hline Indonesia\# & Pre\#\# & Post\#\#\# & Australia\# & Pre\#\# & Post\#\#\# \\
\hline AALI & $-4.89 \mathrm{E}-19^{*}$ & $3.37 \mathrm{E}-19^{*}$ & AAC & 0.00 & $6.41 \mathrm{E}-20$ \\
\hline BISI & $3.46 \mathrm{E}-19^{*}$ & $3.73 \mathrm{E}-19^{*}$ & AVG & $-2.22 \mathrm{E}-19^{*}$ & $2.46 \mathrm{E}-19^{*}$ \\
\hline BTEK & $1.74 \mathrm{E}-18^{*}$ & $-2.12 \mathrm{E}-18^{*}$ & AYB & $2.62 \mathrm{E}-19^{*}$ & 0.00 \\
\hline INDF & $-6.00 \mathrm{E}-19^{*}$ & $4.83 \mathrm{E}-19^{* * *}$ & BUG & $-5.66 \mathrm{E}-20^{* * *}$ & 0.00 \\
\hline LSIP & $2.55 \mathrm{E}-19^{*}$ & 0.00 & CCL & $2.19 \mathrm{E}-19^{*}$ & $-2.43 \mathrm{E}-19 * * *$ \\
\hline ROTI & $2.36 \mathrm{E}-19$ & $-2.39 \mathrm{E}-19$ & CSS & $6.16 \mathrm{E}-19 *$ & $-6.21 \mathrm{E}-19 * *$ \\
\hline SGRO & $2.82 \mathrm{E}-19$ & $-1.87 \mathrm{E}-19$ & FNP & $9.42 \mathrm{E}-19$ & $5.36 \mathrm{E}-19$ \\
\hline TBLA & $-2.50 \mathrm{E}-19 *$ & $3.38 \mathrm{E}-19 *$ & GFF & $-7.79 \mathrm{E}-20^{*}$ & $2.45 \mathrm{E}-20^{*}$ \\
\hline ULTJ & $-1.09 \mathrm{E}-18^{*}$ & $1.34 \mathrm{E}-18^{* *}$ & PFL & $5.12 \mathrm{E}-20 *$ & 0.00 \\
\hline UNSP & $-1.47 \mathrm{E}-19$ & $-7.03 \mathrm{E}-19 * * *$ & SHV & 0.00 & $-6.10 \mathrm{E}-20$ \\
\hline
\end{tabular}

Source: Processed data

Table information:

\# $\quad$ Code of listed corporation in Indonesia and Australia stock exchange

\#\# Corporate performance after income tax incentives implementation in each country

\#\#\# Corporate performance before income tax incentives implementation in each country

* $\quad$ Significant in $1 \%$

** $\quad$ Significant in 5\%

*** $\quad$ Significant in $10 \%$

From table 1, we could analyze the impact of income tax incentives implementation in Indonesia and Australia to corporate performance. Corporate performance are measured with daily return proxy of each corporations, with the basis of income tax incentives will increase corporate net income which in general will increase daily return.

For the cut-off of income tax incentives implementation period, we use December 22, 2011 for Indonesia (the start date of Government Regulation 52/2011) and July 1, 2009 for Australia (the start date of income tax incentives for primary producer).

From the statistic test result, for Indonesia case it is known that $70 \%$ of the samples show an influence of income tax incentives implementation in period before income tax incentives implementation. All evidence is significant in $1 \%$. From samples which show an influence, $57 \%$ show a negative correlation which could be analyzed as without income tax incentives will result in low net income and low return.

Income tax incentives implementation is also significantly influence Indonesian food and agriculture industry. $70 \%$ of Indonesian corporation samples show the evidence of this influence, in which most of it is significant in $1 \%$. From that $70 \%$, we documented a $71 \%$ evidence of positive correlation. This means implementation of income tax incentives resulted in a higher net income, and ultimately a higher return. 
We have found similar result from our Australian data. From our research, we have found $70 \%$ of the samples show an influence of income tax incentives to corporate performance. But it is only $42 \%$ of the samples show a negative correlation, which is slightly lower compared to the Indonesia research where we found a $57 \%$ evidence of negative correlation.

In post-implementation period, we only found $40 \%$ from Australian samples that show the influence of income tax incentives to corporate performance. Interestingly, from this $40 \%$, we have found equal positive and negative correlation evidence. From this result, we could conclude that there is only medium to low magnitude impact of income tax incentives in Australia to corporate performance compared to Indonesian evidence.

From this statistic test result, we also conclude that income tax incentives have a significant impact to corporate performance in food and agriculture industry. Our findings are similar with findings of Anwar and Mulyadi from their research in 2012.

\subsection{Analysis of income tax incentives}

We have summarized the income tax incentives provided by Indonesian and Australian government for food and agricultural industry in table 2 .

Table 2. Summary of income tax incentives for Indonesian and Australian food and agricultural industry

\begin{tabular}{|l|l|l|}
\hline Nature & Indonesia & Australia \\
\hline Net income reduction & $\begin{array}{l}30 \% \text { from investment, equally distributed } \\
\text { in 6 years }\end{array}$ & $\begin{array}{l}\text { Investment in landcare operations, water } \\
\text { facilities (equally distributed in 3 years) and } \\
\text { electricity connections and telephone lines } \\
\text { (equally distributed in 10 years) }\end{array}$ \\
\hline Accelerated expenses & All tangible and intangible assets & Horticultural plants \\
\hline Lower tax rate & For dividend paid to foreign tax subject & N/A \\
\hline $\begin{array}{l}\text { Extended loss carry } \\
\text { forward/profit deferral }\end{array}$ & $\begin{array}{l}\text { Extended loss carry forward up to ten } \\
\text { years }\end{array}$ & Profit deferral for certain circumstances \\
\hline $\begin{array}{l}\text { Net income calculation } \\
\text { method }\end{array}$ & N/A & $\begin{array}{l}\text { Income averaging to avoid market price } \\
\text { fluctuation }\end{array}$ \\
\hline
\end{tabular}

Source: Processed data

From the comparison in table 2, we could conclude that income tax incentives provided for Indonesian food and agricultural industry are comparably more appealing than Australian. For example, in net income reduction: it is a $30 \%$ reduction from any kind of investment. While in Australia, although it is a full reduction, but there are some restriction of the investment which is limited to investment in landcare operations, water facilities, electricity connections and telephone lines.

For accelerated expenses, it is applied to all tangible and intangible assets in Indonesia. As for Australian cases, it is limited to horticultural plants. While for the lower tax rate, it is not available in Australia. In Indonesia, it is available for dividend tax rate that is paid to foreign tax subject. 
Indonesia and Australia have a similar nature in the next income tax incentives. Indonesia provide an extended loss carry forward up to ten years (from originally five years). In Australia, there is a policy of profit deferral on forced disposal, death of livestock, insurance recoveries and double wool clips.

The last income tax incentives provided by Australian government, the usage of income averaging, could be considered by Indonesian government to be applied. This due to the high fluctuation of market price in food and agriculture industry which can cause a significant increase/decrease in corporate net income. The usage of income averaging will result in a more stable net income and also tax liability. Therefore, it is better for the corporate cash flow in relation to amount of tax liability.

Out of five kind of income tax incentives provided by Indonesian and Australian government for food and agricultural industry, we have a conclusion of Indonesian incentives are comparably more appealing than Australian. Our findings are in contrary with the findings of Anwar and Mulyadi (2011a, 2011b, 2012) and Mulyadi, Anwar and Siagian (2012) which concluded income tax incentives provided by Indonesian government are less appealing compared to other countries in the comparison.

\section{Conclusion}

Our research showed a mixed findings to our hypothesis. For some corporations, we have found income tax incentives have a significant influence to corporate performance. In food and agriculture industry, Indonesian and Australian government provide several income tax incentives where those income tax incentives have a significant influence to corporate performance in the industry. However, we have found the Australian influence of income tax incentives to corporate performance is in a less magnitude compared to the Indonesian. While for some other corporations, there are no significant influence of income tax incentives to corporate performance.

Furthermore, we also come to a conclusion that income tax incentives provided by Indonesian government are relatively more appealing compared to Australian income tax incentives. Additional samples from other countries food and agriculture industry such as: USA and New Zealand would be beneficial to be future research in this topic, as we have only discussed two countries in food and agriculture industry tax policy implementation in this research.

\section{References}

Anastassiou, T.A. (2011). Marginal effective tax rates and tax incentive structure evaluation: The case of Greece. Journal of Applied Business Research, 27(4): 1-7.

Anwar, Y., and Mulyadi, M.S. (2011). Income tax incentives on renewable energy industry: Case of geothermal industry in USA and Indonesia. African Journal of Business Management, 5(31): 12264-12270.

Anwar Y. and Mulyadi, M. S. (2011). Income tax incentives on renewable energy industry: Case of USA, China, and Indonesia. The Business Review Cambridge, 17(2): 153-159.

Anwar, Y. and Mulyadi, M. S. (2012). Analysis of income tax incentives for transportation industry in Indonesia. The Business Review Cambridge, 19(2): 323-329. 
Anwar, Y. and Mulyadi, M. S. (2012).Analysis of income tax incentives in Indonesia. Global Business and Economics Research Journal, 1(2): 81-92.

Atkinson, A. B. (1995). Public economics in action. Oxford: Clarendon Press.

Creedy, J. (1995). Taxes and transfers: target efficiency and social welfare. Economica, 63: 163-174.

Deskins, J. A. (2005). Essays on the behavioral effects of tax policy. Dissertation. The University of Tennessee.

Fernandez de Soto Blass, M. L. (2011). Tax incentives to foster green investments under the spotlight of state aids' prohibition. The Business Review Cambridge, 17(2): 68-74.

Grubert, H. and Mutti, J. (1991). Taxes, tariffs and transfer pricing in multinational corporate decision making. The Review of Economics and Statistics, 73(2): 285-293.

Hartman, D. (1984). Tax policy and foreign direct investment in the United States. National Tax Journal, 37(4): 475488.

Hines, J. R. (1996). Altered states: taxes and location of foreign direct investment in America. American Economic Review, 86: 1076-1094.

Holland, D. and Vann, R. J. (1998). Tax law design and drafting. 2nd Volume. International Monetary Fund.

Hutagaol, J., Darussalam and Septriadi, D. (2006). Advance topic in taxation (Kapita selekta perpajakan). Jakarta: Salemba Empat.

Lambert, P. J. (1985). Endogenising the income distribution: The redistributive effect, and laffer effects, of a progressive tax-benefit system. European Journal of Political Economy, 1: 3-20.

Mintz, J. and Smart, M. 2004. Income shifting, investment, and tax competition: Theory and evidence from provincial taxation in Canada. Journal of Public Economics, 88: 1149-1168.

Mulyadi, M. S., Anwar, Y. and Siagian, F. (2012). Study of income tax incentives in creative industry. International Journal of Arts and Commerce, 1(6): 21-24.

Newlon, T. C. (1987). Tax policy and the multinational firm's financial policy and investment decision. Dissertation, Princeton University.

Ondrich, J. and Wasylenko, M. 1993. Foreign direct investment in the United States: Issues, magnitudes, and location choice of new manufacturing plants. Michigan: Upjohn Institute.

Republic of Indonesia. (2011). Indonesian Government Regulation 52/2011. Jakarta: Government of Republic of Indonesia.

Slemrod, J. B. and Blumenthal, M. (1996). The income tax compliance: Cost of big business. Public Finance Quarterly, 24(4): 411-438.

Swenson, D. L. (1994). The impact of US tax reform on foreign direct investment in the United State. Journal of Public Economics, 54: 243-266.

Root, F. R. and Ahmed, A. A. (1978). The influence of policy instruments on manufacturing direct foreign investment in developing countries. Journal of International Business Studies, 9(3): 81-93.

Tung, S. and Cho, S. (2001). Determinants of regional investment decision in China: An econometric model of tax incentive policy. Review of Quantitative Finance and Accounting, 17: 167-185.

Van Parys, S. and James, S. (2010). The effectiveness of tax incentives in attracting investment: panel data evidence from the CFA Franc zone. International Tax and Public Finance. 17: 400-429.

Wasylenko, M. (1997). Taxation and economic development: The state of the economic literature. New England Economic Review, March: 37-52.

Young, K.H. (1988). The effect of taxes and rates of return on foreign direct investment in the United States. National Tax Journal, 41(1): 109-121. 